\title{
Investigation on Promotional Criteria based on Human Resource Practices for Better Organizational Effectiveness
}

\author{
Wong Kok Yaw \\ School of Business Management, \\ Quest International University Perak, Malaysia \\ Email: kokyaw.wong@qiup.edu.my \\ DOI: https://doi.org/10.37134/jcit.vol7.7.2017
}

\begin{abstract}
Promotional decision is one of the important human resource practices that has been seen as a challenge for many organizations. Strong human capital is the successful factor for the development of an organization which can help the company to gain competitive advantage. Promotion criteria which based on seniority, competency, leadership and job attitude are going to discuss in this paper to test their relationship with company performance. 100 human resource executives from different companies will answer the self-directed questionnaire for data collection. Pearson correlation coefficient and multiple regressions will be used to analyse the relationship between independent variables and dependent variable. Results showed that all independent variables are positively related to dependent variable where competency is resulted in highest relationship. Managerial implications are provided to guide managers on the effective promotion criteria for better organizational effectiveness.
\end{abstract}

Keywords Criteria, Competency, Effectiveness, Promotion, Seniority

\section{Introduction}

This study is to discuss the issue regarding human resource practices. One of the common management dilemmas faced by most of the organizations is the promotion should be based on seniority or competencies. Different companies will use different methods to access the criteria for promotion and also their recruitment and selection. In this study, these two different criteria (seniority and competencies) together with some other criteria will be examined and identify which method is more useful to increase the company's performance which lead to higher effectiveness.

\subsection{Research Background}

The economic growth may rely on the performance of the organizations. Emmanuel, Wujung and Emmanuel (2014) found that organizational performance may contribute to the developing of a nation due to the local and foreign direct investments. Therefore, the development of human capital is very important to ensure the growth in the company's performance (Tatlah \& Zafar, 2011). Besides, Batmen \& Snell (2013) noted that human capital is the most critical assets in an organization due to the human knowledge is essential to determine the leadership and management skills. Therefore, company will able to retain the good employees by practicing proper human resource management. Promotion is one of the important methods to keep the employees' loyalty. A good promotion opportunity can help to attract more talented potential employees and reduce their stress and increases their job 
performance (Rowden, Matthews, Watson \& Biggs, 2011). Besides, due to the changes in work setting as well as higher living cost, employees are started to voice out their right for promotion. Therefore, company needs to consider the promotion should be based on seniority or competencies. This management dilemma has been raised the public concern regarding the fairness issue. Different employers have different concepts on promotion criteria which some are agree on seniority but others are argue that it should be based on competence and performance. Organizational culture also plays a role on this issue in determining the requirements for promotion (Lay, Gao \& Tan, 2014).

\subsection{Problem Statement}

The main problem statement to be investigated is to identify the suitable promotion criteria that can lead to the strongest outcome to a company's performance. Promotional decision is very important because it can affect employees' motivation and their work attitude. The outcome may also affect a company's overall effectiveness (Cohen \& Janicki, 2010). Previous studies had shown that promotion is an important human resource management tool to increase the motivation level of employees. According to the Maslow Hierarchy of needs from Abraham Maslow, the basic level of needs is Physiological Need which can be referred to basic pay for employees. People strongly believe that promotion is the way to increase their income to cover raise in cost of living (Batmen \& Snell, 2013). Besides, the highest level of needs from Maslow Hierarchy of needs which is Self-Actualization Need has mentioned that promotion can enhance employee's motivation level that will result in the company overall effectiveness.

Furthermore, a proper promotion scheme can reduce the company's turnover rate (David, 2013). It is one of the strategic management methods that can apply inside the company to retain the employees. Promotion opportunity can encourage the employees to work harder and put more effort. Besides, they are willing to contribute longer service years to get promoted when realized the company will appreciate their outcomes by giving the chance to upgrade their position (Tangthong, Trimetsoontorn \& Rojniruntikul, 2014). In order to examine the relationship between the criteria and company performance, some factors which are seniority, competence, leadership and experiences are selected to test their relationship with company performance. The strongest positive relationship can be identified form this research and apply for managerial implication.

\subsection{Research Objectives}

This study is to identify the criteria of promotion and recognize the relationship between those criteria and company performance. There are four criteria (Independent Variables) will be discussed which are (i) Seniority, (ii) Competency, (iii) Leadership and (iv) Job Attitude.

\subsection{Significance of the Study}

Studies had shown human capital is one of the most important asset of an organization. Promotion opportunity can affect employees' motivation, turnover and company's overall effectiveness. Therefore, finding of this study can assist the employers to understand the proper promotion criteria to improve their employee's retention rates. Besides, it can provide 
role models for new organization on how to practice promotion in human resource management. Gradually, the findings from the study can provide fundamental information and hopes to lay the groundwork for future research while also offering practical recommendations to managers

\section{Literature Review}

\subsection{Role of Human Resource Management in Promotion}

Knowledge is considered very important resources for a company to determine its competitiveness in dynamic economy (Wang \& Noe, 2010). Therefore, knowledge management is critical to make sure the human knowledge can be retained and keep properly in an organization. Some senior managerial personnel will rely on staffing and training system to acquire talented employees by developing the system to transfer expertise and knowledge from one employee to other employees ( $\mathrm{Wu}, \mathrm{Hsu} \&$ Yeh, 2007). However, many previous studies have suggested another effective way to capture and retain the human knowledge is to keep the talented employees from the company by using promotion strategy (Parise, 2007).

Therefore, promotion is becoming one of the fundamentals of human resource management which can retain the good employees, increase employees' motivation and enhance the organizational overall effectiveness. However, promotion has becoming the serious issue of management dilemma faced by many organizations in deciding the promotion's criteria. It is important to maintain the human capital which is a source of sustained competitive advantage (Coff \& Kryscynski, 2011). Xavier (2014) found that the good compensation and benefits management includes the proper promotion strategy. It must be done systematically to make sure the fair treatment for all employees.

\subsection{Seniority}

Seniority is measured by the service years, months and days an employee has work in the same company. Seniority based promotion is the system that looks at the length of service in the company to weigh the promotional opportunity in an organization. This kind of promotion criteria normally will be applied in eastern culture businesses (Casati \& Genet, 2014). Rawes (2014) found that this promotion criteria has been applied since many years ago and mostly applied by organizations that practiced traditional management culture such as centralization. It is the decision making authority fall on top management. Some managers believed that seniority is a good criteria because it is representing the experience of an employee had gathered in the company which is helpful to increase the productions. It is because they are able to contribute their experience to increase the company's performance (Samii, 2011). Besides, it can maintain a harmony workplace which help promotes the social system stability by reducing the competition and conflict among employees. It will result in better stability and higher company effectiveness.

However, many previous studies found that getting lesser organizations are solely depend on seniority based promotion due to its several disadvantages. It will make employees create the assumption that longevity is the only way to get promoted regardless their ability, leadership and performance (Heathfield, 2014). It can result in serious problem for a company 
in long term. Besides, this criteria is not able to enhance the talented employees' motivation because they may have no chance to get promoted when their service length is shorter than those are less ability to become a manger. This issue will cause talented workers not willing to wait for their promotion turn and leave from the company (Marquis, 2014). Therefore, the turnover rate is increasing and company is forced to pay higher to recruit externally.

H1: Seniority based promotion is positively related to company performance.

\subsection{Competency}

Competency is the ability of an employee to perform the task in order to increase the company overall performance. Promotion based on competency sometimes also named as promotion based on merit or performance based promotion. It is a good way to promote the employees who have better qualification for the position than others who have the greater seniority (Billikopf, 2007). Many previous studies had shown that the performance based promotion is an important human resource management strategy to raise the motivation among employees in order to achieve better organizational performance (Boachie-Mensah \& Dogbe, 2011). It can be further examine by apply the Expectancy Theory developed by Pearce and Perry in 1983. From this theory, particular level of performance will lead to the particular level of outcome and the outcome will link to the valence (Bateman \& Snell, 2013). Therefore, Perry, Engbers and Jun (2009) found that the performance based promotion can lead the employees to work harder if they believe the promotion will result from their increased in efforts. It is considered a healthy environment for an organization because employees are willing to put effort for the better position. It can also increase the company's overall performance and effectiveness.

Promotion based on competency is viewed as an unbiased review system (Gomez, 2014). It is because this system is based on employee's ability to carry out the task and promotion is only for those who put more effort with better competencies compare to others. Besides, this criteria can incorporate into organizational culture which can help to increase productivity, morale and reduce turnover (Browne, 2014). Employees will believe that company will treat them fairly and everyone has the equal chance to get promoted. Therefore, they are more willing to put effort to show their competence which can increase the production outcome and enhance overall company's effectiveness (Stavrou \& Ierodiakonou, 2013).

H2: Competency based promotion is positively related to company performance.

\subsection{Leadership}

Leadership is the ability to influence employees to voluntarily pursue organizational goals. Leadership is also the complementary system of action for dealing with change through setting direction, aligning people and motivating and inspiring (Kinicki \& Williams, 2011). This is one of the common criteria used by the company to determine the promotion. There are two types of leaderships can be found in an organization which are transactional and transformational leaderships. Transactional leadership is about the use of management functions and provides the rewards for good performance and gives the punishments for bad performance (Bateman \& Snell, 2013). Transactional leadership is transforming employees to 
pursue organizational goal over their self-interests (Kinicki \& Williams, 2011). Previous studies found that the role of leadership is important in promotion strategy to keep the talented employees in order to increase the organizational performance (Birasnav, 2014). It is also about the knowledge management by how a company can retain expertise workers in workplace. As discussed in previous section, it can be done through promotion.

Collert, Kristof-Brown, Bradley \& Barrick (2008) found that transformational leadership is better for the criteria for promotion. It is because this leadership helps to focus on employee morale and engagement. If a manager has this transformational leadership, he can provide the role model for his subordinates to create a better culture in the organization. Therefore, it can increase a company performance. Besides, employees with the transformational leadership will focus the new ideas and transform the organization into better culture (Yucei, McMillan \& Richard, 2013). This is one of the criteria to become a managerial person when talking about promotion to higher level position.

H3: leadership based promotion is positively related to company performance.

\subsection{Job Attitude}

Job attitude is the evaluations of one's job that make up one's feeling toward, beliefs about and attachment to the job. Previous studies had shown that positive job attitude is one of the promotion criteria because managers with good job attitude will has better communication with subordinates and better commitment to their responsibilities (Kehoe \& Wright, 2013). Positive job attitude will link to a better company performance. Employee with positive attitude will work better in workplace because they can process information with greater awareness and efficiency (Reeves, 2014). Besides, it can make the employee to be more responsive in the work environment. Work attitude is also related to the motivation (Archer, 2014). The bad attitude can lead to conflict and create a poor environment. Motivation level of the employees will reduce in this situation. Furthermore, positive job attitude can promote growth and progressiveness which lead to higher productivity (Reeves, 2014).

However, positive job attitude is not the only criteria for promotion. Researchers found that this is important for a manager but there are some other criteria such as competence or performance based will add more value for a managerial position, especially senior management level (Russo, Guo \& Baruch, 2014). Manager needs to perform management function (planning, organizing, leading and controlling) by applying managerial skills (technical, human and conceptual skills) in their daily operations (Bateman \& Snell, 2013). Therefore, positive attitude is not sufficient for a person in higher position.

H4: Job attitude based promotion is positively related to company performance.

\section{Proposed Research Framework}

This framework identifies the relationship between the Independent Variables (IV) [IV 1 : Seniority, IV: Competency, $\mathrm{IV}_{3}$ : Leadership and $\mathrm{IV}_{4}$ : Job Attitude] and Dependent Variable (DV) [DV: Company Performance]. 


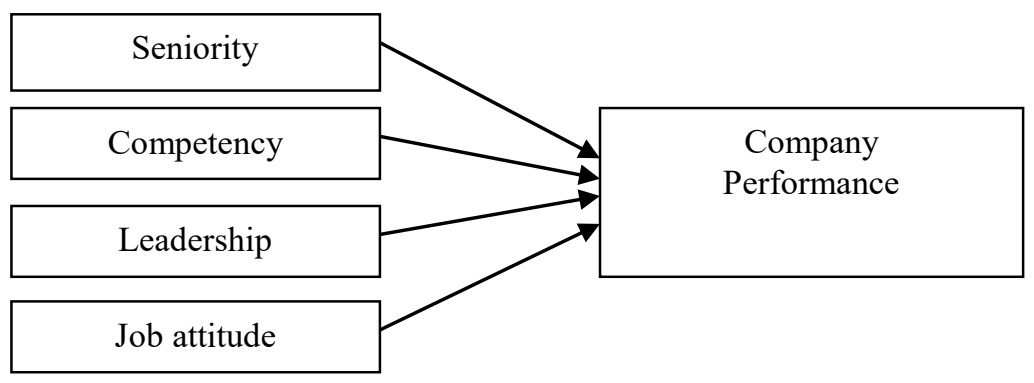

Figure 1 Promotion criteria that affect the company performance

\section{Research Methodology}

Quantitative research will be conducted in this study as it is often used to collect and analyze based on numerical data, and generalize the results from large samples (Lodico, Spaulding \& Voegtle, 2010). In addition, descriptive research and correlation study are being used in this study in order to achieve the objective. Sampling frame or name list of target respondents was not available due to the difficulty of locating the member of population (Babbie, 2013). A total of 100 samples were collected for this study. Target respondents are human resource executives from different companies locates at urban areas which consist of higher populations such as are Selangor, Perak and Penang (United Nations Development Programme [UNDP], 2011). Self-reported questionnaires is given to collect data from target respondents.

The computer program that has been used to analyse data is Excel 2010. In this analysis, Pearson correlation coefficient and multiple regressions will be used to analyse the relationship between independent variables and dependent variable.

\section{Results and Analysis}

\subsection{Descriptive analysis}

Table 1 Frequency table

\begin{tabular}{|l|l|l|}
\hline Items & Frequency & Cumulative \% \\
\hline Age & 20 & 20 \\
\hline Below 25 & 30 & 50 \\
\hline $25-35$ & 35 & 85 \\
\hline $36-45$ & 15 & 100 \\
\hline Above 45 & 100 & \\
\hline Total & \multicolumn{2}{l|}{} \\
\hline \multicolumn{2}{|l|}{} \\
\hline Educational level & 25 & 25 \\
\hline Diploma/ Certification & 70 & 95 \\
\hline Bachelor Degree &
\end{tabular}




\begin{tabular}{|l|l|l|}
\hline Postgraduate & 5 & 100 \\
\hline Others & - & \\
\hline Total & 100 & \\
\hline \multicolumn{2}{|l|}{} \\
\hline Number of years worked & \multicolumn{2}{|l|}{} \\
\hline Less than 5 years & 10 & 10 \\
\hline $5-10$ years & 35 & 45 \\
\hline $11-15$ years & 40 & 85 \\
\hline Above 15 years & 15 & 100 \\
\hline Total & 100 & \\
\hline
\end{tabular}

\subsection{Inferential \& reliability analysis}

\subsubsection{Summary of Pearson Correlations Coefficient}

Table 2 Pearson Correlations Coefficient (Independent variables with dependent variable)

\begin{tabular}{|c|c|c|c|}
\hline & \multicolumn{3}{|c|}{ Company performance } \\
\cline { 2 - 5 } & Pearson Correlation & Sig (2 tailed) & $\mathrm{N}$ \\
\hline Seniority & $0.404^{*}$ & 0.044 & 100 \\
\hline Competency & $0.769^{*}$ & 0.000 & 100 \\
\hline Leadership & $0.489^{*}$ & 0.029 & 100 \\
\hline Job attitude & $0.524^{*}$ & 0.018 & 100 \\
\hline
\end{tabular}

* Correlation significant at the 0.05 level (2 tailed)

Analysis of Pearson Correlations Coefficient results based on Table 2 above:

\begin{tabular}{|c|c|c|}
\hline $\begin{array}{l}\text { H1: Seniority based promotion } \\
\text { is positively related to company } \\
\text { performance. }\end{array}$ & $\begin{array}{l}\text { P-value is } 0.044 \text { which is less than significant level of } 0.05 \text {. } \\
\text { Thus, the relationship is significant. The value of this } \\
\text { correlation coefficient } 0.404 \text { showing the relationship is small. }\end{array}$ & $\begin{array}{l}\mathrm{H} 1 \\
\text { accepted }\end{array}$ \\
\hline $\begin{array}{l}\text { H2: Competency based } \\
\text { promotion is positively related } \\
\text { to company performance. }\end{array}$ & $\begin{array}{l}\text { P-value is } 0.000 \text { which is less than significant level of } 0.01 \text {. } \\
\text { Thus, the relationship is significant. The value of this } \\
\text { correlation coefficient } 0.769 \text { showing the relationship is high. }\end{array}$ & $\begin{array}{l}\mathrm{H} 2 \\
\text { accepted }\end{array}$ \\
\hline $\begin{array}{l}\text { H3: leadership based promotion } \\
\text { is positively related to company } \\
\text { performance. }\end{array}$ & $\begin{array}{l}\text { P-value is } 0.029 \text { which is less than significant level of } 0.01 \text {. } \\
\text { Thus, the relationship is significant. The value of this } \\
\text { correlation coefficient } 0.489 \text { showing the relationship is } \\
\text { moderate. }\end{array}$ & $\begin{array}{l}\text { H3 } \\
\text { accepted }\end{array}$ \\
\hline $\begin{array}{l}\text { H4: Job attitude based } \\
\text { promotion is positively related } \\
\text { to company performance. }\end{array}$ & $\begin{array}{l}\text { P-value is } 0.018 \text { which is less than significant level of } 0.01 \text {. } \\
\text { Thus, the relationship is significant. The value of this } \\
\text { correlation coefficient } 0.524 \text { showing the relationship is } \\
\text { moderate. }\end{array}$ & $\begin{array}{l}\mathrm{H} 4 \\
\text { accepted }\end{array}$ \\
\hline
\end{tabular}




\subsubsection{Summary of Multiple Regression Analysis}

Table 3 Model summary

\begin{tabular}{|l|r|}
\hline Regression Statistics & \\
\hline Multiple R & 0.803197473 \\
\hline R Square & 0.645126181 \\
\hline Adjusted R Square & 0.550493163 \\
\hline Standard Error & 0.656186127 \\
\hline Observations & 100 \\
\hline
\end{tabular}

The value of correlation coefficient ( $\mathrm{R}$ value) for this study is 0.80 which fall under range of \pm 0.71 to \pm 0.90 . Therefore, the relationship between independents variables (seniority, competency, leadership and job attitude) and dependent variable (company performance) is high. In this study, independents variables can explain $55 \%$ of the variations in dependent variable (company performance).

\section{Conclusion}

A number of the findings from the analysis have relevance to the growing knowledge base regarding the promotion criteria that can increase the company performance. In conclusion, the four independent variables (Seniority, Competency, Leadership and Job Attitude) are significant to predict occupational stress in this study. There are some previous studies agreed with the findings from this study. For seniority based promotion, previous researches mentioned that company cannot solely based on seniority to determine the promotion (Heathfield, 2014; Marquis, 2014). Besides, there are also previous researches strongly recommended companies to use performance based or competency based to determine the promotion (Billikopf, 2007; Engbers \& Jun, 2009; Stavrou \& Ierodiakonou, 2013). In terms of leadership from managers, some studies believe it is useful to enhance company performance (Birasnav, 2014; Yucei, McMillan \& Richard, 2013). Another independent variable, job attitude is also recommended to determine the promotion (Reeves, 2014; Archer, 2014). However, a company cannot solely depend on one criteria but need to consider more when promote its employee to better position.

From the study, competency is found to be the predictor variable that contributes the highest variation score in occupational stress. The second highest predictor variable is leadership follows by job attitude and seniority contributes the least in this study. The organization is advised to use competency as the first consideration for promotion criteria. On the same time, organization should access more criteria such as leadership, job attitude and seniority. However, seniority should be given the least consideration since it has the weak relationship with company performance. A proper human resource management strategy can help the organization to reduce or avoid paying the high price for the occupational stress and demoralization faced by employees. The price could be high turnover, undesirable job performance, impaired worker morale and even increased legal expenses in an organization. 


\subsection{Managerial Implications}

Practical implications for policy makers and practitioners are provided to improve the company performance through the appropriate promotion criteria. Competency is found to be one of the promotion criteria that has the greatest positive impact on company performance. Therefore, company should pay more attention on this criteria when promote the employees to better positions. It is because competency based promotion is agreed by most of the employees and they believe this is a fair criteria to determine the right person for the right position. Therefore, employees' motivation level can be enhanced and lead to a better company performance. Competency should be given the first priority and treated as the most important attribute for promotion.

Seniority based promotion is least desired by employees because it may not help to increase company performance much. This criteria is found to have small relationship with company performance. However, it is still significant to explain the relationship. Therefore, a company cannot solely depends on seniority but must combine with other criteria such as competency (the most important), leadership and job attitude when prepare for promotion assessments.

\subsection{Limitation}

Two limitations are identified in conducting this investigation. Firstly, using self-reported questionnaires might leave a lot of room for 'response biases'. Paulhus (1991) stated that some respondents tend to answer the questionnaire while not basing it on their actual thinking or behavioural patterns as required of some questions. Instead of answering honestly, the respondents may tend to use their answers to paint themselves more favorably. Since the selfreported is based on honest reporting of human behaviour, the biased responses would certainly undermine its credibility as a behavioural measure.

Secondly, there is still leave $45 \%$ unexplained in this study based on the results from the multiple regression analysis. In other words, there are additional variables that are important in explaining occupational stress that have not been considered in this study. Therefore, there are some other important promotion criteria may yet to be discovered to identify their significant relationship with the company performance.

\section{Acknowledgement}

I owe my deepest gratitude to those who have helped me by giving guidance, support, and cooperation in this research. I also wish to thank the respondents for answering the questionnaires. Their valuable responses had helped much in generating input, shorten the data collection period and made this research possible.

\section{References}

Archer, J. (2014). Work attitudes \& motivation in the workplace. Retrieved from http://woman.thenest.com/workattituds-motivation-workplace-114 65 .html 
Bateman, T.S., \& Snell, S.A. (2013). Management: Leading \& collaborating in a competitive world (10th ed.). New York: McGraw-Hill.

Babbie, E. (2013). The basics of social research. Cengage Learning.

Boachie-Mensah, F., \& Dogbe, O.H. (2011). Performance based pay as a motivational tool for achieving organizational performance: An Exploratory case study. International Journal of Business and Management, 6(12), $1-17$.

Billikopf, G. (2007). Promotions, transfers \& layoffs. Retrieved from http://www.cnr.berkeley.edu/ucce50/aglabor/7labor/04.htm

Birasnav, M. (2014). Knowledge management and organizational performance in service industry: The role of transformational leadership beyond the effects of transactional leadership. Journal of Business Research, 1(3), 18.

Brown, C. (2014). The impact of merit pay on job performance. Retrieved from http://www.ehow.com/info_10060482_impact-merit-pay-job-performance.html

Casati, A., \& Genet, C. (2014). Principle investigators as scientific entrepreneurs. Journal of Technology Transfer, 39(1), 11-32.

Coff, R., \& Kryscynski, D. (2011). Invited editorial: Drilling for micro-foundations of human capital based competitive advantage. Journal of Management, 37(5), 1429-1443.

Cohen, P.N., \& Huffman, M.L. (2007). Working for the women, female managers and the gender wage gap. Journal of American Sociological Review, 72(5), 681-704.

Collert, A., Kristof-Brown, A., Bradley, B., \& Barrick, M. (2008). CEO transformational leadership: The role of goal importance congruence in top management teams. Journal of Academy of Management, 51, 81-96.

David, F.R. (2013). Strategic Management. Concept and cases (14th ed.). United States: Pearson Education Limited.

Gomez, C. (2014). What are the benefits of merit based pay. Retrieved from http://www.ehow.com/info_7752963_benefits-meritbased-pay.html

Emmanuel, O.N.B., Wujung, V.A., \& Emmanuel, S.M.P. (2014). Mechanisms of the influence of human capital on economic growth: A panel data analysis of the Cemac region. Asian Economic and Financial Review, 4(5), 625640.

Hair, J.F., Money, A.H., Samouel, P., Page, M. (2007). Research methods for business. Chichester, West Sussex: John Wiley \& Sons, Inc.

Heathfield, S.M. (2014). What seniority means to work. Retrieved February 14, 2014, from http://humanresources.about.com/od/workplaces-organizations/g/what-is-seniority-in-theworkplace.htm

Kehoe, R.R., \& Wright, P.M. (2013). The impact of high performance human resource practices on employees' attitudes and behavior. Journal of Management, 39(2), 366-391.

Kinicki, A., \& Williams, B. (2011). Management: A practical introduction (5 $5^{\text {th }}$ ed.). New York: McGraw Hill International.

Lay, M.L., Gao, S.H., \& Tan, S.P. (2014). The analysis on the cultural creativities, itinerary and field shaping of the indigenous people in Taiwan: Taking the Laij Tribe and the Tjimur Tribe for example. International Journal of Social Science and Humanity, 4(3), 170-177.

Lodico, M.G., Spaulding, D.T., \& Voegtle, K.H. (2010). Methods in educational research: From theory to practice. United States: John Wiley and Sons.

Marquis, A. (2014). Pros $\mathcal{E}$ cons of a seniority based system of promotion and transfer. Retrieved from http://www.ehow.com/info_8671371_pros-based-system-promotion-transfers.html

Parise, S. (2007). Knowledge management and human resource development: An application in social network methods. Advances in Developing Human Resources, 9(3), 359-383.

Paulhus, D.P. (1991). Measurement and control of response bias. In Robinson, J.P., Shaver, P.R., \& Wrightsman, L.S. (Eds.), Measures of personality and social psychological attitudes (pp. 17-59). San Diego: Academic Press.

Perry, J.L., Engbers, T.A., \& Jun, S.Y. (2009). Back to the future. Performance related pay, empirical research and the perils of resistance. Public Administration Review, 69(1), 33-51.

Rawes, E. M. (2014). What is the seniority system and how was it declined in important? Retrieved from http://www.ehow.com/info_12085942_seniority-system-declined-importance.html

Reeves, L. (2014). How do negative \& positive attitudes affect the workplace. Retrieved February 14, 2014, from http://woman.thenest.com/negative-positive-attitudes-affect-workplace-2811.html

Rowden, P., Matthews, G., Watson, B., \& Biggs, H. (2011). The relative impact of work-related stress, life stress and driving environment stress on driving outcomes. Journal of Accident Analysis \& Prevention, 43(4), 1332-1340. 
Russo, M., Guo, L., \& Baruch, Y. (2014). Work attitudes, career success and health: Evidence from China. Journal of Vocational Behavior, 84(3), 248-258.

Samii, M. (2011). Changing structure of Japanese management and corporate governance. International Journal of Governance, 1(2), 13-18.

Stavrou, E., \& Ierodiakonou, C. (2013). Flexibility for women returners in Cyprus: A competency based approach. International Journal of Gender in Management, 28(1), 6-27.

Tangthong, S., Trimetsoontorn, J., \& Rojniruntikul, N. (2014). The effect of HRM practices on employee attrition in Thailand Manufacturing. International Journal of Social Science and Humanity, 4(6), 498-503.

Tatlah, I.A., \& Zafar, I.M. (2011). Role of human capital and education in economic growth. International Journal of Academic Research, 32(2), 629-631.

United Nations Development Programme. (2011). Malaysia achieving the millennium development goals: Successes and challenges. Kuala Lumpur: United Nations Country Team.

Wang, S., \& Noe, R.A. (2010). Knowledge sharing: A review and directions for future research. Human Resource Management Review, 20, 115-131.

Wu, W.L., Hsu, B.F., \& Yeh, R.S. (2007). Fostering the determinants of knowledge transfer: A team level analysis. Journal of Information Science, 33(3), 326-339.

Xavier, B. (2014). Shaping the future research agenda for compensation and benefits management: Some thoughts based on a stakeholder inquiry. Human Resource Management Review, 24, 31-40.

Yucei, I., McMillan, A., \& Richard, O.C. (2013). Does CEO transformational leadership influence top executive normative commitment? Journal of Business Research, 1-8.

Zikmund, W.G., Babin, B.J., Carr, J.C., \& Griffin, M. (2010). Business research the methods (8th ed.). New York: SouthWestern/Cengage Learning. 